\title{
HANNOVER RADIOCARBON MEASUREMENTS V
}

\author{
M. A. GEYH
}

Niedersächsisches Landesamt für Bodenforschung Hannover, Germany

\section{INTRODUCTION}

This date list contains a selection of $\mathrm{C}^{14}$ dates of geological samples obtained from March 1963 until July 1966. The preceding date lists (Hannover I, III, IV) give a description of preparation and measuring methods.

The $\mathrm{C}^{14}$ ages were calculated with Libby's half-life of $5568 \mathrm{yr}$. The year of reference is 1950 . The modern standard has been taken as $95 \%$ of NBS oxalic-acid for organic samples. Variations of isotope fractionation were not considered in the calculation of $\mathrm{C}^{14}$ dates because the age shifts caused by them lie within the statistical limits of error. Infinite ages were stated on criterion of $+2 \sigma$ above background, according to $97.5 \%$ probability for the confidence interval.

Abbreviations in the following text are N.L.f.B. for Niedersächsisches Landesamt für Bodenforschung, Hannover (Germany); B.f.B. for Bundesanstalt für Bodenforschung, Hannover (Germany); and G. L. for Geologisches Landesamt.

The author thanks Erika Guhlich, Renate Eichhorn and Norgart Lutz for their excellent work in chemical preparation and measurement of samples, Heinrich Schneekloth for helpful discussion, and all submitters of samples for their comments.

\section{SAMPLE DESCRIPTIONS}

\section{A. Germany}

\section{Kehdingen series, Niedersachsen}

Sphagnum peat from Kehdinger Moor, near Hammelwörden. Coll. 1964 and subm. by Heinrich Schneekloth, N.L.f.B. Age determinations of recurrence horizon (SWK) from 8 different profiles within region of same bog were made both by $\mathrm{C}^{14}$ and by pollen-analysis (H. Schneekloth). Stratigraphically, profiles were typical of raised bogs, with dark and light peat above valley bog peat and thick marine clay (Schneekloth, 1967a).

\section{Kehdingen, Profile 1, 80 to $90 \mathrm{~cm} \quad 150$ B.c.}

Sphagnum acutifolia peat, directly above SWK $\left(53^{\circ} 45^{\prime} 24^{\prime \prime} \mathrm{N}\right.$ Lat, $9^{\circ} 16^{\prime} 51^{\prime \prime}$ E Long).

Sphagnum acutifolia peat, from same boring as $\mathrm{Hv}-664$. 
Hv-666. Kehdingen, Profile 2, 80 to $90 \mathrm{~cm} \quad$ A.D. 330

Sphagnum cymbifolia peat, directly above SWK $\left(53^{\circ} 45^{\prime} 55^{\prime \prime} \mathrm{N}\right.$ Lat, $9=14^{\prime} 34^{\prime \prime}$ E Long).

\section{Hv-667. Kehdingen, Profile 3,60 to $70 \mathrm{~cm}$}

$1850 \pm 70$

Sphagnum acutifolia peat, directly above SWK $\left(53^{\circ} 43^{\prime} 40^{\prime \prime} \mathbf{N}\right.$ Lat, 9. $17^{\prime} 59^{\prime \prime}$ E Long).

\section{Hv-668. Kehdingen, Profile 4, 95 to $105 \mathrm{~cm}$}

Sphagnum acutifolia peat, directly above SWK $\left(53^{\circ} 43^{\prime} 51^{\prime \prime} \mathrm{N}\right.$ Lat, $9 \div 16^{\prime} 20^{\prime \prime}$ E Long).

\section{Hv-669. Kehdingen, Profile 5a, 100 to $108 \mathrm{~cm}$}

$2030 \pm 80$

Sphagnum cymbifolia peat, directly above SWK $\left(53^{\circ} 44^{\prime} 30^{\prime \prime} \mathrm{N}\right.$ Lat, $9=17^{\prime} 50^{\prime \prime} \mathrm{E}$ Long).

$1895 \pm 75$

Hv-670. Kehdingen, Profile 5b, 10 to $110 \mathrm{~cm}$ A.D. 55

Sphagnum cymbifolia peat, directly above SWK (534 44' $27^{\prime \prime}$ N Lat, $9=17^{\prime} 56^{\prime \prime}$ E Long).

Hv-671. Kehdingen, Profile 6, 95 to $105 \mathrm{~cm}$

$2035 \pm 80$

85 B.c.

Sphagnum cymbifolia-cuspidata peat, directly above SWK $\left(53^{\circ} 45^{\prime}\right.$ $57^{\prime \prime}$ N Lat, 9० $16^{\prime} 1^{\prime \prime}$ E Long).

\section{Hv-672. Kehdingen, Profile 7, 65 to $73 \mathrm{~cm}$ A.D. 105}

Sphagnum acutifolia-cuspidata peat, directly above SWK $\left(53^{\circ} 44^{\prime}\right.$ $37^{\prime \prime}$ N Lat, 9० 16' 12" E Long).

General Comment (H.S.): pollen-analytical dating yielded age differences for a single recurrence horizon in different profiles of same bog which are satisfactorily confirmed by $\mathrm{C}^{1 \pm}$ dating (Schneekloth, 1967a). The fact that SWK of same bog is not necessarily of same age was already verified in Gifhorn bog (Hannover III; Schneekloth, 1965).

\section{Sievershausen series, Niedersachsen}

Peat samples from five bogs of different developmental type in Southern Niedersachsen mountain region (Solling mountains). Coll. 1963,1964 and subm. by H. Schneekloth. In connection with geological mapping, they were subjected to pollen-analytical (by H. Schneekloth) and $\mathrm{C}^{14}$ dating in order to get deeper knowledge on development of bogs and forest history in this area.

\section{Hv-604. Torfmoor, 50 to $60 \mathrm{~cm}$}

$$
1060 \pm 50
$$

Sphagnum acutifolia peat, slightly decomposed, from a boring $\left(51^{\circ}\right.$ $45^{\prime} 33^{\prime \prime} \mathrm{N}$ Lat, 9० $33^{\prime} 44^{\prime \prime}$ E Long). 
Hv-605. Torfmoor, 110 to $120 \mathrm{~cm}$

$1625 \pm 60$

Sphagnum-Eriophorum peat, from same boring as Hv-604.

Hv-606. Torfmoor, 190 to $200 \mathrm{~cm}$

$3515 \pm 80$

Sphagnum acutifolia peat, from same boring as Hv-604.

Hv-607. Torfmoor, 280 to $290 \mathrm{~cm}$

$4100 \pm 75$

sphagnum acutifolia peat, from same boring as Hv-604.

Hv-608. Torfmoor, 330 to $380 \mathrm{~cm}$

$5000 \pm 75$

Sphagnum acutifolia peat, from same boring as Hv-604.

Hv-609. Torfmoor, 390 to $400 \mathrm{~cm}$

$4875 \pm 75$

Birch-wood peat, from same boring as Hv-604.

Comment: some important pollen-floristical characteristics (Steckhan, 1961) were to be checked by $\mathrm{C}^{11}$. Good conformity was established.

Hv-601. Mecklenbruch, 100 to $110 \mathrm{~cm}$

$1720 \pm 70$

Sphagnum acutifolia peat, slightly decomposed, from a boring $\left(51^{\circ}\right.$ $46^{\prime} 55^{\prime \prime} \mathrm{N}$ Lat, $9^{\circ} 33^{\prime} 30^{\prime \prime}$ E Long).

Hv-600. Mecklenbruch, 200 to $210 \mathrm{~cm}$

$2630 \pm 80$

680 в.C.

Sphagnum acutifolia peat, slightly decomposed, from same boring as $\mathrm{Hv}-60 \mathrm{l}$.

Hv-908. Mecklenbruch, 270 to $280 \mathrm{~cm}$

$3180=80$

1230 B.c. Hv-601.

Sphagnum acutifolia peat, slightly decomposed, from same boring as

Hv-907. Mecklenbruch, 350 to $360 \mathrm{~cm}$

$3485=80$

1535 B.C.

Strongly decomposed Sphagnum-Carex peat with birch-wood, from same boring as Hv-601. Comment (H.S.): some important pollen-floristical characteristics (Knörzer, 1949) were to be checked by $\mathrm{C}^{14}$. As far as the relatively atypical pollen diagram will permit evaluation, final results are in accordance with presumptions.

Hv-906. Ahlequellemoor, 50 to $60 \mathrm{~cm}$

$3935 \pm 80$

Forest-bog B.c. Long).

1985 B.c.

$\begin{array}{lll}\text { Hv-599. Ahlequellemoor, } 120 \text { to } 130 \mathrm{~cm} & \mathbf{5 6 9 0} \pm 80 \\ \mathbf{3 7 4 0} \text { в.c. }\end{array}$

Carex peat with wood remains, from same boring as Hv-906. Com- 
ment (H.S.): investigations clarify process of Holocene peat transformation of the graben, of Tertiary origin, near Neuhaus. The considerable age of uppermost peat layers was surprising, but it does not contradict pollen-analytical results.

Forest-bog peat from a boring (51 $46^{\prime} 9^{\prime \prime} \mathrm{N}$ Lat, 9० $35^{\prime} 21^{\prime \prime}$ E Long). Comment: dating served to correlate pollen diagram, covering a short period of time, with $\mathrm{C}^{14}$ time scale.

Hv-905. W-Hülsebruch, 50 to $60 \mathrm{~cm}$

$3190 \pm 75$

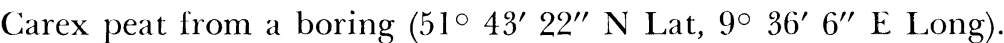

\section{Hv-904. W-Hülsebruch, 110 to $120 \mathrm{~cm}$}

$4385 \pm 85$

Forest-bog peat, from same boring as Hv-905. Comment (H.S.): dating served to correlate pollen diagram, covering a short period of time, with $\mathrm{C}^{14}$ time scale.

General Comment (H.S.): dates prove the time of approx. 3500 в.c. for beginning of continuous Fagus curve, approx. 900 B.C. for rapid increase of Fagus curve, approx. 1200 B.C. for Corylus peak C IV, and approx. A.D. 750 for beginning of continuous cereal curve; less than $100 \mathrm{~km}$ away from Solling mountains, increase of the Fagus curve in Harz mountains was dated approx. 1600 в.c. (Willutzki, 1962). Pollenanalytical and $\mathrm{C}^{14}$ dates within and between profiles could be correlated (Schneekloth, 1967b).

\section{Zwillbrocks series, Westfalen}

Samples originate from exposure in Zwillbrock Venn (52 $52^{\prime} 55^{\prime \prime}$ N Lat, $6^{\circ} 41^{\prime} 27^{\prime \prime}$ E Long). Coll. 1964 and subm. by Ernst Burrichter, Bot. Inst. of Univ., Münster. $\mathrm{C}^{14}$ and pollen-analytical datings were carried out to investigate vegetational development of Zwillbrock Venn and forest history of surroundings. Pollen-analysis by E. Burrichter.

Hv-806. Zwillbrock, $53 \mathrm{~cm}$

$1400 \pm 100$

Sphagnum peat was correlated, by presence of cereal pollen, to end of period of interrupted settlement, i.e. the time of mass migration.

Hv-806. Zwillbrock, 53 cm

$1655 \pm 100$

Sphagnum peat was correlated, by absence of cereal pollen, to beginning of period of interrupted settlement at time of mass migration.

Hv-808. Zwillbrock, $78 \mathrm{~cm}$

$3620 \pm 110$

Cyperaceae peat, pollen-analytically dated, because of start of rational beech curve, at 1500 B.C. 
Hv-807. Zwillbrock, 95 cm

$5315 \pm 120$

3365 B.c.

Cyperaceae peat, not datable by pollen-analysis, because of contorted profile.

Hv-610. Zwillbrock, $120 \mathrm{~cm}$

$6045 \pm 75$

Charcoal from charred layer in forest peat, correlated by pollenanalysis to a time after elm decline.

General Comment (E.B.): $\mathrm{C}^{1+}$ and pollen-analytical dates are correlated and show that age for time of elm decline and of beech dispersal of Westfälische Bucht is older than that for Emsland and Dutch bogs, because immigration of trees took place from $\mathrm{S}$.

\section{Dätgen series, Holstein}

Peat samples directly below and above SWK, from an exposure of Grosse Moor near Dätgen (54 $9^{\prime} 42^{\prime \prime}$ N Lat, $9^{\circ} 55^{\prime} 12^{\prime \prime}$ E Long), from three profiles in the immediate neighbourhood. Coll. 1963 and subm. by Ludwig Aletsee, Bot. Inst. der Univ., Kiel. Dating should clear problem of whether SWK in hummocks and hollows a short distance apart would be of equal age, and of whether the hiatus determined by pollen-analysis (Aletsee, 1959) really reflects a break in bog growth. Pollen-analysis by L. Aletsee.

\section{Hv-673. Dätgen, Profile A-I}

$2755 \pm 65$

Slightly decomposed light peat, 0 to $2 \mathrm{~cm}$ above SWK.

\section{Hv-674. Dätgen, Profile A-I}

805 B.C.

Slightly decomposed dark peat, 0 to $2 \mathrm{~cm}$ below SWK.

\section{Hv-675. Dätgen, Profile A-II}

$2995 \pm 65$

1045 B.c.

Slightly decomposed light peat, 0 to $2 \mathrm{~cm}$ above SWK.

\section{Hv-676. Dätgen, Profile A-II}

$2820 \pm 80$

870 в.c.

Slightly decomposed dark peat, 0 to $2 \mathrm{~cm}$ below SWK.

\section{Hv-677. Dätgen, Profile A-III}

$2820 \pm 80$

870 в.C.

Slightly decomposed light peat, 0 to $2 \mathrm{~cm}$ above SWK ; sample fro same layer dated by Heidelberg (subm. 1961 by L Als, $2860+70$, H-1590a/1139, unpub.) and by Kiel (subm. 1964 by L. Aletsee, 2470 \pm 90 , KI-65, unpub.).

\section{Hv-678. Dätgen, Profile A-III}

$$
2935 \pm 80
$$

Slightly decomposed dark peat, 0 to $2 \mathrm{~cm}$ below SWK; sample from same layer dated by Heidelberg (subm. 1961 by L. Aletsee, $2965 \pm 60$; 
H-1590b/1257, unpub.) and by Kiel (subm. 1964 by L. Aletsee, $2500 \pm$ 80; KI-64, unpub., and $2700 \pm 200$, KI-11; Kiel 1966).

General Comment (L.A.): by pollen-analysis, no age differences can be established for SWK horizons of Profiles A-I, A-II and A-III. All belong to Zone IX/X (of Firbas, 1949). In Profile A-I, SWK has hummock position. Stronger humification underneath SWK indicates a temporary stagnation of peat growth. Humification above and below the recurrence horizon of Profile A-II, taken in a hollow, is little different. Profile A-III shows a sharply defined SKW which suggests a shorter phase of stagnation in peat growth towards end of dark peat period. However, SWK is of same $\mathrm{C}^{14}$ age in all Profiles.

\section{Schöhsee series, Holstein}

Sedimentary samples from boring in the Schöhsee $\left(54^{\circ} 9^{\prime} 58^{\prime \prime} \mathrm{N}\right.$ Lat, $10^{\circ} 26^{\prime} 4^{\prime \prime}$ E Long). Coll. 1964 by Massoud Saad; subm. by Waldemar Ohle, Hydrolog. Anstalt (Max-Planck-Gesell.), Plön. Pollen-analytical and $\mathrm{C}^{14}$ investigations were carried out to explore history of levelopment of the Schöhsee. Pollen-analysis by W. Ohle.

\section{Hv-1058. Schöhsee, 200 to $235 \mathrm{~cm}$ \\ $3125 \pm 100$} Sample was pollen-analytically correlated to Zone $\mathrm{X} / \mathrm{XI}$.

Hv-1059. Schöhsee, 235 to $265 \mathrm{~cm}$

$3240 \pm 115$

Sample is pollen-analytically of same age as $\mathrm{Hv}-1058$.

Hv-1060. Schöhsee, 500 to $530 \mathrm{~cm}$

$7515 \pm 195$

5565 в.C.

Sample was pollen-analytically correlated to middle of Zone VIII. General Comment: dates give information on speed of sedimentation in the Schöhsee.

\section{Marsh series, Schleswig-Holstein}

Peat samples from various borings in Schleswig-Holstein Marsh region of North Sea coast. Stratigraphic sequence shows alternatively silty clay and little-decayed peat, sporadically occurring down to $-20 \mathrm{~m}$. Clay layers can be assigned to the well-known five pre-Christian transgressions. Coll. 1961 by Georg Brand, Burchard Mencke and Siegfried Bressau; subm. by Adolf Dücker, G. L. Schleswig-Holstein, Kiel. C ${ }^{14}$ and pollen-analytical dates serve to distinguish different flooding sequences of North Sea and to adapt Schleswig-Holstein chronology of the marine Holocene to the Dutch one (Brand and others, 1965). Pollen-analysis by R. Averdiek and B. Mencke.

\section{Hv-176. Meldorf, 127 to $140 \mathrm{~cm}$}

Weakly clayey Phragmites peat from a boring $\left(54^{\circ} 7^{\prime} 15^{\prime \prime} \mathrm{N}\right.$ Lat, $9^{\circ} 8^{\prime} 26^{\prime \prime}$ E Long), overlain by silty clay of the Schwabstedt bed. Pollenanalytically dated as late sub-Boreal. 
Hv-179. Meldorf, 315 to $335 \mathrm{~cm}$

$4160 \pm 125$

2210 B.c.

Carex peat from same boring as Hv-176, underlain by Husum bed; pollen-analytically classified as early sub-Boreal.

Hv-181. Meldorf, 459 to $475 \mathrm{~cm}$

$5480 \pm 135$

3530 B.C.

Phragmites peat from same boring as $\mathrm{Hv}-176$, underlain by silty clay of Eesch bed; pollen-analytically dated as late Atlantic.

\section{Hv-183. Meldorf, 581 to $591 \mathrm{~cm}$}

$7825 \pm 100$

5875 B.c.

Forest-bog peat from same boring as $\mathrm{Hv}-176$, overlain by silty clay from Eesch bed.

\section{Hv-184. Meldorf, 660 to $670 \mathrm{~cm}$}

$9230 \pm 100$

Forest-bog peat from same boring as $\mathrm{Hv}-176$, overlain by silty clay of Barlt bed.

\section{Hv-185. Meldorf, 707 to $727 \mathrm{~cm}$}

$11,950 \pm 130$

ing as Hv-176, overlain by gyttja and woment: $\mathrm{C}^{1+}$ dates are in conformity with pollen-analysis and show that ages of both older marine transgressions (Barlt and Eesch) are higher than expected geologically.

\section{Hv-629. Delve, 545 to $560 \mathrm{~cm}$}

$6130 \pm 85$

Phragmites peat of a boring $\left(54^{\circ} 18^{\prime}\right.$ I marks termination of first transgression traceable in $15^{\prime} 40^{\prime \prime} \mathrm{E} \mathrm{Long)}$ bed).

\section{Hv-622. Delve, 1280 to $1290 \mathrm{~cm}$}

$9750 \pm 115$

Peat from same boring as Hv-629. Comment: pollen-analy. dated to early Boreal (Zone VI of Overbeck). Dating pollen-analytically of whether the older dating (7600 в.c.) or the new one (approx. 6900 B.c.) (Straka, 1961) is valid.

\section{Hv-631. Delve, 305 to $320 \mathrm{~cm}$}

$4395 \pm 100$

Peat from boring $\left(54^{\circ}\right.$ termination of termination of second transgression in this region. Comment: end of the flooding is given in the Netherlands as 2300 B.c. (De Jong, 1960).

\section{Hv-627. Delve, 490 to $500 \mathrm{~cm}$}

$4860 \pm 275$

Phragmites peat from a boring $\left(54^{\circ} 18^{\prime} 3^{\prime \prime} \mathrm{N}\right.$ Lat, 9० $15^{\prime} 40^{\prime \prime} \mathrm{E}$ Long); marks start of elm decline. Comment: pollen-analytically dated approx. 3000 в.c. (Willutzki, 1962). 
Hv-628. Wallen, 1180 to $1200 \mathrm{~cm}$

$6945 \pm 90$

4995 B.c.

Forest-bog peat from a boring $\left(54^{\circ} 17^{\prime} 27^{\prime \prime} \mathrm{N}\right.$ Lat, 9० $15^{\prime} 51^{\prime \prime} \mathrm{E}$ Long); marks start of transgression in this region (Eesch bed). Age conformable with $\mathrm{Hv}-217$, Hv-218, Hv-222.

\section{Hv-767. Bergewöhrden, 80 to $90 \mathrm{~cm}$}

$1715 \pm 65$

Peat from a boring in raised bog of Bergewöhrden (54 $18^{\prime} 38^{\prime \prime} \mathrm{N}$ Lat, $9^{\circ} 13^{\prime} 58^{\prime \prime} \mathrm{E}$ Long), immediately above recurrence horizon; pollenanalytically, break in Carpinus-curve and beginning of Secale pollen point to short stratigraphic hiatus in post-Christian time (Nietsch, 1958).

\section{Hv-768. Bergewöhrden, 95 to $100 \mathrm{~cm}$}

$$
\begin{gathered}
2010 \pm 65 \\
60 \text { в.c. }
\end{gathered}
$$

Peat from same boring as $\mathrm{Hv}-767$, immediately below SWK; pollenanalysis shows beginning of Carpinus spread approx. 1950 B.c. (Kubitzki, 1961).

Hv-766. Bergewöhrden, 140 to $150 \mathrm{~cm}$

$2405 \pm 80$

Peat from same boring as $\mathrm{Hv}-767$; marks beginning of last preChristian transgression (Schwabstedt bed); pollen-analytically classified to main phase of Fagus dominanee in Zone VIII/IX (Firbas, 1949).

\section{Hv-765. Bergewöhrden, 180 to $190 \mathrm{~cm}$}

$3010 \pm 70$

Sample from same boring as $\mathrm{Hv}-767$; marks pollen-analytically beginning of Corylus decline (approx. 1100 B.C.).

\section{Hv-764. Bergewöhrden, 235 to $245 \mathrm{~cm}$}

$3640 \pm 85$

Peat from same boring as Hv-767; marks Meldorf bed (Lüttig, 1965). Comment: $\mathrm{C}^{14}$ and pollen-analytical dates of Bergewöhrden peat samples confirm previous ideas about sequence of transgressions in this region.

Hv-231. Husum, 40 to $50 \mathrm{~cm}$

$1090 \pm 90$

Peat from a boring (54 $26^{\prime} 29^{\prime \prime} \mathrm{N}$ Lat, $9^{\circ} 6^{\prime} 7^{\prime \prime}$ E Long); marks beginning of first post-Christian flooding.

Hv-243. Husum, 137 to $148 \mathrm{~cm}$

Peat from a boring (54 $26^{\prime} 5^{\prime \prime} \mathrm{N}$ Lat, $9^{\circ} 4^{\prime} 43^{\prime \prime}$ E Long): corresponds to top of Schwabstedt bed.

\section{Hv-237. Husum, 110 to $120 \mathrm{~cm}$}

$$
2520 \pm 90
$$

570 B.C.

Peat from a boring (54 $27^{\prime} 42^{\prime \prime} \mathrm{N}$ Lat, 9 $9^{\circ} 3^{\prime} 27^{\prime \prime} \mathrm{E}$ Long); corresponds to beginning of Schwabstedt bed in conformity with pollenanalytical results (Hv-766). 


\section{Hv-242. Husum, 210 to $220 \mathrm{~cm}$}

$3110 \pm 80$

Peat from same boring as Hv-243; corresponds to top of Meldorf bed.

Hv-220. Husum, 195 to $205 \mathrm{~cm}$

$\mathbf{3 5 0 0} \pm \mathbf{8 0}$

Peat from a boring (54 $25^{\prime} 20^{\prime \prime} \mathrm{N}$ Lat, $9^{\circ} 1^{\prime} 19^{\prime \prime} \mathrm{E}$ Long); stratigraphically close to top of Meldorf bed.

Hv-229. Husum, 200 to $215 \mathrm{~cm}$ $4000 \pm 80$

Peat from same boring as $\mathrm{H}_{\mathbf{2}} 231$; marks beginning of flood quence IV in Schleswig-Holstein.

Hv-241. Husum, 257 to $267 \mathrm{~cm}$

$3620 \pm 115$

Peat from same boring as $\mathrm{Hv}-243$; stratigraphically corresponds to beginning of Meldorf bed ( $\mathrm{Hv}-229, \mathrm{Hv}-215)$.

Hv-215. Husum, 335 to $345 \mathrm{~cm}$

$3670 \pm 100$

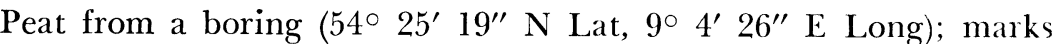
beginning of flood sequence IV (Meldorf bed).

Hv-219. Husum, 240 to $250 \mathrm{~cm}$

$4450 \pm 80$

2500 B.c.

Peat from same boring as $\mathrm{Hv}-220$; stratigraphically corresponds to upper Fiel bed (Hv-228).

\section{Hv-228. Husum, 300 to $315 \mathrm{~cm}$}

$4730 \pm 100$

Peat from same boring as $\mathrm{Hv}-231$; stratigraphically classified into upper Fiel-bed (Hv-219).

\section{Hv-213. Husum, 710 to $750 \mathrm{~cm}$}

$\mathbf{5 7 4 0} \pm \mathbf{8 0}$

Shell sample from a boring (54 $24^{\prime} 6^{\prime \prime} \mathrm{N}$ Lat, $9^{\circ} 3^{\prime} 12^{\prime \prime} \mathrm{E}$ Long) from lower Fiel bed.

\section{Hv-232. Husum, 530 to $440 \mathrm{~cm}$}

$6050 \pm 170$

Basal peat from a boring (54 $27^{\prime} 8^{\prime \prime} \mathrm{N}$ Lat, 9० $5^{\prime} 32^{\prime \prime} \mathrm{E}$ Long), lying underneath Fiel bed.

Hv-238. Husum, 647 to $662 \mathrm{~cm}$

$5740 \pm 110$ in Schleswig-Holstein (Hv-226).

Hv-226. Husum, 730 to $745 \mathrm{~cm}$

$5930 \pm 90$

Peat from same boring as Hv-231; stratigaphically $\mathbf{3 9 8 0}$ B.C. II-B flooding (Hv-238). 
Hv-224. Husum, 800 to $815 \mathrm{~cm}$

Basal peat from a boring (54 $26^{\prime} 45^{\prime \prime} \mathrm{N}$ Lat, $9^{\circ} 6^{\prime} 0^{\prime \prime} \mathrm{E}$ Long), directly below Eesch bed.

Hv-222. Husum, 950 to $960 \mathrm{~cm}$

$6500 \pm 140$

4550 в.C.

Basal peat from same boring as $\mathrm{Hv}-231,10 \mathrm{~cm}$ below Eesch bed. Pollen-analytically of same age as Hv-628.

\section{Hv-217. Husum, 1310 to $1320 \mathrm{~cm}$}

$7100 \pm 125$

5150 B.c.

Basal peat from a boring (54 $24^{\prime} 14^{\prime \prime} \mathrm{N}$ Lat, 9० $\mathrm{l}^{\prime} 45^{\prime \prime}$ E Long), 20 $\mathrm{cm}$ below Eesch bed (Hv-628).

\section{Hv-218. Husum, 1140 to $1150 \mathrm{~cm}$}

$7500 \pm 170$

Basal peat from same Boring as $\mathrm{Hv}-220,30 \mathrm{~cm}$ below Eesch bed (Hv-628).

\section{Hv-225. Husum, 795 to $810 \mathrm{~cm}$}

$8400 \pm 100$

Basal peat from same Boring as Hv-231, $25 \mathrm{~cm}$ below Eesch bed. General Comment: pollen-analytical and $\mathrm{C}^{14}$ results are in excellent agreement. Dates permit classification of the marine Holocene on North Sea coast of Schleswig-Holstein, which has many parallels to Dutch and Niedersachsen classifications. Common to all the three regions is occurrence of four different transgressions prior to Christian era. Thus, beginning of Eesch bed must have been approx. 5000 B.c.; that of Fiel bed approx. 3500 в.c.; that of Meldorf bed approx. 1900 в.c., that of Schwabstedt bed approx. 600 в.c. (Brand and others, 1965).

\section{Bordelum series, Nordfriesland}

Peat samples from three profiles from raised bog in Bordelum (54 ${ }^{\circ}$ $37^{\prime} 57^{\prime \prime} \mathrm{N}$ Lat, $8^{\circ} 55^{\prime} 13^{\prime \prime}$ E Long). Coll. 1964 and subm. by Rolf Wiermann, Bot. Inst. der Univ., Kiel. $\mathrm{C}^{1+}$ dates clarify the bog and marsh history in S-Nordfriesland. Pollen-analytical results (Wiermann, 1962) are to be tested against $\mathrm{C}^{1+}$ time scale. Pollen-analysis by $\mathrm{R}$. Wiermann.

\section{Hv-644. Bordelum, Profile A, 63 to $66 \mathrm{~cm}$}

$1370 \pm 60$

Fen peat of 0 to $3 \mathrm{~cm}$ below peat/clay contact.

$$
\text { A.D. } 580
$$

Hv-650. Bordelum, Profile B, 109 to $112 \mathrm{~cm}$

$$
1570 \pm 65
$$

Fen peat of 0 to $3 \mathrm{~cm}$ below peat/clay contact.

Hv-653. Bordelum, Profile C, 63 to $66 \mathrm{~cm}$

$$
\text { A.D. } 380
$$

$$
\begin{array}{r}
1600 \pm 60 \\
\text { A.D. } 350
\end{array}
$$

Fen peat of 0 to $3 \mathrm{~cm}$ below peat/clay contact. Comment: the calculated average value of A.D. $440 \pm 40$ for beginning of flooding that 
caused formation of peat/clay contact agrees well with pollen-analytical results.

Hv-645. Bordelum, Profile A, 66 to $69 \mathrm{~cm}$ Fen peat of 3 to $6 \mathrm{~cm}$ below peat/clay contact.

Hv-652. Bordelum, Profile B, 66 to $69 \mathrm{~cm}$ Fen peat of 3 to $6 \mathrm{~cm}$ below peat/clay contact.

Hv-654. Bordelum, Profile C, 66 to $69 \mathrm{~cm}$ Fen peat of 3 to $6 \mathrm{~cm}$ below peat/clay contact.

\section{Hv-643. Nordstrandischmoor, 50 to $55 \mathrm{~cm}$}

Slightly decomposed Sphagnum peat from a boring $\left(54^{\circ} 33^{\prime} 3^{\prime \prime} \mathrm{N}\right.$ Lat, $8^{\circ} 48^{\prime} 14^{\prime \prime}$ E Long).

General Comment: dates fix age of a pollen-analytically equivalent level (rapidly increasing Fagus curve) over large area of marshes on coast of North Sea (Wiermann, 1966).

\section{Dornum series, Niedersachsen}

Peat from two borings in marsh sediment near Dornum. Sample layer is overlain by calcareous silty clay and underlain by sand. Coll. 1963 and subm. by H. D. Lang, N.L.f.B. Samples date marsh sediments.

Hv-543. Dorum, 2.0 to $2.2 \mathrm{~m}$

$2710 \pm 50$

760 B.C.

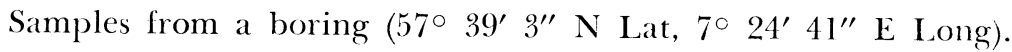

\section{Hv-545. Dorum, 2.6 to $2.8 \mathrm{~m}$}

$4070 \pm 120$

Sample from same profile as Hv-543.

Hv-542. Dorum, 2.0 to $2.2 \mathrm{~m}$

$3160 \div 70$

Sample from a boring (5339' $11^{\prime \prime} \mathrm{N}$ Lat, $7^{\circ} 24^{\prime} 32^{\prime \prime} \mathrm{E}$ Long).

\section{Hv-544. Dorum, 2.6 to $2.8 \mathrm{~m}$}

$4010=90$

Sample from same boring as $\mathrm{Hv}-542$.

General Comment (H.D.L.): in view of geological situation and altitude of peat layers, ages varying from 3000 to 4000 B.P. were expected (Müller, 1962). Peat growth in this region was estimated at approx. $80 \mathrm{~cm} / 1000$ yr.

\section{Leppersum series, Niedersachsen}

Peat samples from an exposure in marsh near Leppersum (53 $26^{\prime}$ $\mathrm{N}$ Lat, $7^{\circ}$ 12' E Long). Coll. 1965 and subm. by Manfred Renger, N.L.f.B. Samples correlate Holocene transgressions of North Sea. 


\section{Hv-891. Leppersum, Profile 11}

$1680 \pm 70$ 1962 ).

Sample, depth 74 to $76 \mathrm{~cm}$, stratigraphically placed in jo (Müller,

\section{Hv-889. Leppersum, Profile 150}

$2015 \pm 75$

Sample, depth 47 to $49 \mathrm{~cm}$, from same layer as $\mathrm{Hv}-891$.

65 B.c.

\section{Hv-890. Leppersum, Profile 150}

$3805 \pm 80$

1855 в.C.

Sample, depth 110 to $115 \mathrm{~cm}$, from stratigraphical layer $\mathrm{ju} \mathrm{u}_{2}$.

General Comment (M.R.): good agreement with pollen-analysis and other $C^{14}$ dates from same region (Müller, 1962) was achieved.

\section{Hr-1158. Dalheim, Nordrhein-Westfalen}

$1805 \pm 70$

Charcoal from a charred layer, depth 55 to $60 \mathrm{~cm}$, near Dalheim (51 $34^{\prime} 25^{\prime \prime} \mathrm{N}$ Lat, $8^{\circ} 48^{\prime} 40^{\prime \prime} \mathrm{E}$ Long), embedded in loess loam. Coll. 1965 and subm. by E. von Zezschwitz, G. L. Nordrhein-Westfalen, Krefeld. Comment: according to former geologic concepts, covering of charred layer by loess loam should have taken place after clearing period in Middle ages, approx. 13th century A.D. $\mathrm{C}^{14}$ age is in conformity with stratigraphy.

\section{Geislingen series, Baden-Württemberg}

Samples from various core drillings near Geislingen $\left(48^{\circ} 36^{\prime} 30^{\prime \prime} \mathrm{N}\right.$ Lat, $9^{\circ} 50^{\prime} 34^{\prime \prime}$ E Long). Stratigraphic sequence shows alternating beds of humus mud and calcareous tuffs. Coll. 1965 and subm. by Paul Groschopf, G. L. Baden-Württemberg, Stuttgart. Samples date postglacial valley sediments, in particular the calcareous tuffs and mud from Rohrach valley in Schwäbische Alb.

\section{Hv-971. Geislingen, Profile 7, $6.5 \mathrm{~m}$}

$8305 \pm 100$

Birchwood from peat layer, overlain by mud and underlain by calcareous tuffs, from higher stratigraphic position than $\mathrm{Hv}-1147$ and Hr-975.

\section{Hv-972. Geislingen, Profile 7, $7.3 \mathrm{~m}$}

$7880 \pm 105$

5930 в.c.

Calcareous mud, underlain by pure mud, overlain by peat.

\section{Hv-973. Geislingen, Profile 7, $10.0 \mathrm{~m}$}

$9420 \pm 115$

7470 B.C.

Calcareous mud underlain by calcareous tuff.

Hv-974. Geislingen, Profile 7, $12.5 \mathrm{~m}$

$9840 \pm 110$ 7890 B.c.

Wood from basal mud; a sample from same layer was dated by Heidelberg $(9290 \pm 190, \mathrm{H}-126 / 143$, unpub.); stratigraphically the same laver as $\mathrm{Hv}-1148$. 
Hv-975. Geislingen, Profile 140, $7.0 \mathrm{~m} \quad 5670$ B.c. as $\mathrm{Hv}-1147$.

Hv-1147. Geislingen, Profile 8, $9.5 \mathrm{~m}$

$6870 \pm 90$

Peat overlain by calcareous tuff and underlain by mud, from same layer as $\mathrm{Hv}-975$, but lying deeper.

Hv-1148. Geislingen, Profile 8, $15.0 \mathrm{~m}$

Peat mud underlain by calcareous mud and gravels. Stratigraphically the same layer as $\mathrm{Hv}-974$.

General Comment (P.G.): datings of basal mud from neighbourhood confirm age of samples Hv-1148 and Hv-974 (Groschopf, 1961). Investigations proved that 15 -m-thick calcareous tuff layers may form in less than $5000 \mathrm{yr}$; thus they provide some insight into climatic cycle of Southern Germany. Age of $\mathrm{Hv}-971$ is not explainable. Calculation of $\mathrm{C}^{14}$ ages of calcareous mud was done under assumption of a $\mathrm{C}^{14}$ recent activity of $85 \%$ modern.

\section{Hv-546. Nienhagen, Nordrhein-Westfalen}

$10,730 \pm 105$

8780 B.C.

Peat sample and wood from an exposure, depth $3 \mathrm{~m}$, at cuesta of Werra valley near Nienhagen (51 $57^{\circ} 14^{\prime \prime} \mathrm{N}$ Lat, $8^{\circ} 49^{\prime} 23^{\prime \prime} \mathrm{E}$ Long), overlain by driftsand, underlain by low-terrace sand. Coll. 1963 and subm. by Heinrich Wortmann, G. L. Nordrhein-Westfalen, Krefeld. Comment (H.W.): according to Stoller's stratigraphy (Stroller, 1916), the driftsands originated from Eem interglacial period. Pollen-analysis by H. Rehhagen, G. L. Krefeld, suggested correlation with Zone IIb of Firbas (approx. 11,850 to 10,850 B.P.). Thus driftsands must be regarded as low-terrace sediments of the Alleröd.

\section{Hv-656. Adelsheim, Baden-Wuirttemberg}

$21,500 \pm 800$

Calcareous tuff from a recent exposure, depth $0.9 \mathrm{~m}$, near Adelsheim (49 24' 13" N Lat, 9॰23' 43" E Long). Sample stems from a Muschelkalk outcrop $15 \mathrm{~m}$ above valley floor; it was found in a tuffaceous layer of several meters' thickness. Coll. 1964 and subm. by Helmut Prier, G. L. Baden-Württemberg, Freiberg. Comment: examination of the gastropod fauna revealed frequent occurrence of Belgrandia germanica, which is said to have died out at end of Riss-Würm interglacial (approx. 120,000 yr) (Maeck, 1963). $\mathrm{C}^{14}$ result indicates contamination, perhaps by infiltrated water.

\section{Hv-732. Neukirchen, Nordrhein-Westfalen}

Wood from freezing shaft, dept $14 \mathrm{~m}$, in valley of Rhein river near Neukirchen ( $51^{\circ} 26^{\prime} 38^{\prime \prime} \mathrm{N}$ Lat, $6^{\circ} 33^{\prime} 12^{\prime \prime} \mathrm{E}$ Long), imbedded in gravels of the river Rhein. Coll. 1964 and subm. by Karl Thomé, G. L. 
Nordrhein-Westfalen, Krefeld. Comment: sample intended to date middle terrace sediments which, according to geological findings, may originate from Postglacial or Holstein Interglacial (Moeser-Schichten) (Steeger, 1952). It is not Postglacial.

\section{Celle series, Niedersachsen}

Charcoal from an exposure near Celle $\left(52^{\circ} 37^{\prime} 34^{\prime \prime} \mathrm{N}\right.$ Lat, $10^{\circ} 5^{\prime} 00^{\prime \prime}$ E Long), stratigraphic sequence shows $1 \mathrm{~m}$ rubble, $3 \mathrm{~m}$ fluviatile sand, underlain by thin peat layer, underlain in turn by pebbles. Coll. 1964 and subm. by H. D. Lang. Dates served the investigation of a geological profile in Aller glacial channel, composed of Holocene and Pleistocene layers (Lang, 1965).

\section{Hv-615. Celle, $2.5 \mathrm{~m}$}

$11,150 \pm 150$

9200 B.C.

Hv-616. Celle, 3 to $6 \mathrm{~m}$

$\mathbf{3 0 , 1 5 0} \pm \mathbf{8 0 0}$

28,200 в.C.

Comment: from provisional geological findings, a Weichsel glacial age for sample was originally assumed without the possibility of a more exact assignment.

\section{Voltlage series, Niedersachsen}

Humic acid from podsol samples from a test trench in B-horizon near Voltlage $\left(56^{\circ} 26^{\prime} 22^{\prime \prime} \mathrm{N}\right.$ Lat, $7^{\circ} 46^{\prime} 25^{\prime \prime} \mathrm{E}$ Long), overlain by fine sands. Surface is overgrown by oak birch woods. Coll. 1962 and subm. by Rudolf Lüders, N.L.f.B. Samples date minimum age of podsolic material, taken from B-horizon.

\section{Hv-379. Voltlage, 50 to $55 \mathrm{~cm}$}

$$
2710 \pm 100
$$

Hv-380. Voltlage, 115 to $130 \mathrm{~cm}$

$2020 \pm \mathbf{3 0 0}$

Comment: samples stem from a strongly developed podsolic horizon giving the impression of a relatively old soil. Its formation was interrupted by fluviatile erosion (Lüders, 1964).

\section{Hv-593. Wimbachgries, Bayern}

$\mathbf{3 3 0} \pm \mathbf{5 0}$

Wood from exposure in talus, depth $60 \mathrm{~cm}$, near Wimbachgries $\left(47^{\circ}\right.$ $33^{\prime} 14^{\prime \prime} \mathrm{N}$ Lat, $12^{\circ} 52^{\prime} 13^{\prime \prime} \mathrm{E}$ Long), over- and underlain by dolomitic gravels. Coll. 1963 and subm. by Ortwin Ganss, G. L. Bayern, München. Comment: sample dates a landslide caused by torrential rainfall. According to palynological investigations of a peat horizon, approx. A.D. 1100 was a probable date.

Hv-594. Berchtesgaden, Bayern

Wood from exposure from bottom of Laros river $\left(47^{\circ} 38^{\prime} 8^{\prime \prime} \mathrm{N}\right.$ Lat, $13^{\circ} 3^{\prime} 35^{\prime \prime}$ E Long). Coll. 1953 and subm. by O. Ganss. Comment: dating 
of sample as Interglacial follows from stratigraphic position (Ganss, 1953).

\section{Hv-527. Kuhgrund I, Niedersachsen}

$45,900 \pm 800$

Coniferous trunk from exposure at Elbe river bluff, depth $11.5 \mathrm{~m}$

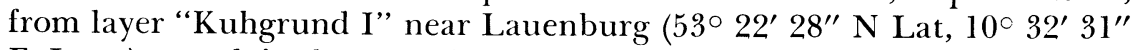
E Long), overlain by gravels. Coll. 1963 and subm. by Klaus Meyer, N.L.f.B. Comment: according to pollen-analysis (Schüttrumpf, 1937), bed belongs to Eem Interglacial. Two samples of same trunk, carefully pretreated with $\mathrm{NaOH}$, furnished identical results.

\section{Lüneburger Elbmarsch series, Niedersachsen}

Samples from various depth in test trenches and borings in the Elbmarsch near Lüneburg, embedded in clays and sands. Coll. 1964 and subm. by Heinrich Benzler, N.L.f.B. Datings served age classification of the Elbmarsch. In glaciofluvial sands of Elbe river valley there existed, at beginning of Holocene, glacial channels that later were overblown by dunes. On them formed podsols. Elbe river deposited sands and clays that inter-finger with peat.

\section{Hv-662. Lauenberg, 1.7 to $1.9 \mathrm{~m}$}

$4060 \pm 100$

Clayey peat from uppermost part of peat deposit of deepest channel, $4 \mathrm{~m}$ below sealevel, from a boring $\left(53^{\circ} 20^{\prime} 10^{\prime \prime} \mathrm{N}\right.$ Lat, $10^{\circ} 30^{\prime} 27^{\prime \prime} \mathrm{E}$ Long), overlain by clayey sands.

\section{Hv-561a. Lauenburg, 4.6 to $4.7 \mathrm{~m}$}

$8420 \pm 80$ Hv-662.

Peat from lowermost part of peat deposit from same profile as

\section{Hv-308. Tespe, 1.3 to $1.5 \mathrm{~m}$}

Clayey fen peat from uppermost part of peat deposit, in chance

$2 \mathrm{~m}$ above sealevel, from a boring $\left(53^{\circ} 23^{\prime} 35^{\prime \prime} \mathrm{N}\right.$ Lat, $10^{\circ} 24^{\prime} 35^{\prime \prime} \mathrm{E}$ Long); layer was stratigraphically classified in $-\mathrm{u}_{2}$ (Müller, 1962).

Hv-309. Tespe, 3.1 to $3.2 \mathrm{~m}$

$4990 \pm 70$

Clayey fen peat from lowermost part of deposit from same profile as $\mathrm{Hv}-308$; layer was stratigraphically classified in $-\mathrm{m}_{3}$.

Hv-558. Bütlingen, 0.7 to $0.8 \mathrm{~m}$

$1310 \pm 60$

Peat from a "Humusdwog," 4 to $4.5 \mathrm{~m}$ above sealevel, from a test

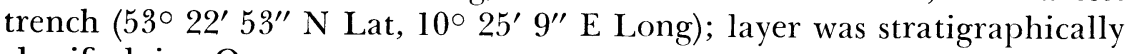
classified in $-\mathrm{O}_{1}$.

Hv-559. Artlenburg, 0.9 to $1.0 \mathrm{~m}$

$$
\mathbf{1 4 8 0} \pm \mathbf{5 0}
$$

Peat from humic channel fill, 4 to $4.5 \mathrm{~m}$ above sealevel, from a test 


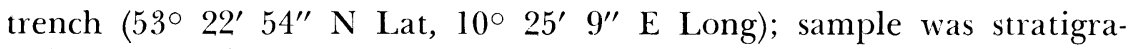
phically classified in $-\mathrm{O}_{1}$.

Hv-560. Lauenburg, 1.1 to $1.2 \mathrm{~m}$

$$
1020 \pm 50
$$

Uppermost peat layer from bog near a dune, from an exposure $\left(53^{\circ}\right.$ $20^{\prime} 52^{\prime \prime}$ N Lat, $10^{\circ} 34^{\prime} 37^{\prime \prime}$ E Long).

\section{Hv-561. Lauenburg, 1.9 to $2.0 \mathrm{~m}$}

$2480 \pm 60$

Lowermost peat layer from same profile as $\mathrm{Hv}-560$.

530 B.C.

\section{Hv-713. Artlenburg, 1.0 to $1.5 \mathrm{~m}$}

$3770 \pm 75$

1820 B.C.

Charcoal from bleached zone of a podsol grown on a dune $\left(53^{\circ} 21^{\prime}\right.$ $51^{\prime \prime} \mathrm{N}$ Lat, $10^{\circ} 26^{\prime} 26^{\prime \prime}$ E Long). Comment: dates show that sedimentation and peat formation in Lüneburg Elbmarsch took place during the Holocene and that sequence of sedimentation can be classified into the scheme (Müller, 1962) established for coastal marsh regions (Benzler, 1965).

\section{Triponzo series, Italy}

\section{B. Foreign Countries}

Wood from exposure of a river terrace, $60 \mathrm{~m}$ thick, in travertine

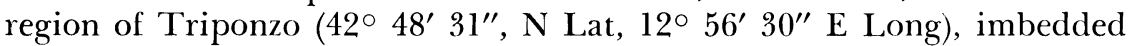
in humic clay, travertine and travertine sands. Coll. 1965 and subm. by Rainer Vinken, N.L.f.B. Samples date river terrace.

Hv-1134. Triponzo, $2.0 \mathrm{~m}$

$$
\begin{aligned}
& 3085 \pm 75 \\
& 1135 \text { в.c. } \\
& 4120 \pm 85 \\
& 2170 \text { в.c. } \\
& 6275 \pm 90 \\
& 4325 \text { в.c. } \\
& 8240 \pm 175 \\
& 6290 \text { в.c. }
\end{aligned}
$$$$
\text { Hv-1133. Triponzo, } 12.0 \mathrm{~m}
$$$$
\text { Hv-1436. Triponzo, } 34.0 \mathrm{~m}
$$

Hv-1434. Triponzo, $48.0 \mathrm{~m}$

Comment: because of its altitude, river terrace was assigned to late Pleistocene. Ages of the interbedded wood samples point to formation during young Holocene. Therefore, it was concluded that in travertine regions the altitude and thickness of alluvial terraces may be misleading.

\section{Hv-518. Strymon river, Greece}

$3440 \pm 100$

Wood from natural exposure, depth $4 \mathrm{~m}$, in alluvial terrace, height $20 \mathrm{~m}$, on Strymon river (44 $55^{\prime} \mathrm{N}$ Lat, $23^{\circ} 30^{\prime} \mathrm{E}$ Long), overlain by loamy sands and gravels. Coll. 1963 and subm. by Hubert Körber, N.L.f.B. Comment: sample dates the surprisingly young terrace accumulation. Black-band-ceramics indicate approx. 5000 в.c. 


\section{Hv-1145. Fisching-Asten, Austria}

Wood from gravel pit, depth 10 to $12 \mathrm{~m}$, in Fisching-Asten (48 $14^{\prime} 10^{\prime \prime} \mathrm{N}$ Lat, $14^{\circ} 25^{\prime} 10^{\prime \prime} \mathrm{E}$ Long), imbedded in postglacial sands and gravels. Coll. 1965 and subm. by Hermann Kohl, Naturkundliche Station, Linz. Comment: dating was performed to fix age of gravel layers in Donau valley. Because of position below low terrace, post-glacial age was assumed. Sample from stratigraphical layer was dated by Wien (subm. by H. Watzl, Linzer Stadtmuseum; VRI-18; $4390 \pm 90$; unpub.). Dates indicate agglomeration of catastrophic character, up to $12 \mathrm{~m}$ thick, approx. 2000 B.C.

\section{Hv-1265. New Abu Simbel, Egypt}

Probably weathered Corbicula shells from surface of Masmas formation near New Abu Simbel (24 25' $0^{\prime \prime} \mathrm{N}$ Lat, $33^{\circ} 2^{\prime} 30^{\prime \prime}$ E Long). Coll. 1964 by Karl Butzer, Univ. of Wisconsin, Madison; subm. by Gerd Lütig, N.L.f.B. Comment: sample stems from layer belonging to Middle Sebilian culture (13,000 B.C. \pm 1000$)$.

\section{Hv-1139. Salina, Sicily}

Charcoal below tuffs from cover of a glacio-eustatic Mediterranean terrace, depth 3 to $4 \mathrm{~m}$, on Isle of Salina $\left(38^{\circ} 33^{\prime} 42^{\prime \prime} \mathrm{N}\right.$ Lat, $14^{\circ} 51^{\prime} 47^{\prime \prime}$ E Long). Coll. 1965 and subm. by Jörg Keller, Geol. Inst. der Univ., Freiburg, Germany. Comment: according to earlier geological concepts (Wolstedt, 1958), terrace corresponds to postglacial climatic optimum. New results show (Zeuner, 1959) that sealevel may have had same high position also in second Interstadial.

\section{Hv-809. Larissa, Greece}

Lignite from exposure in steep bank of Pinios river, depth $7.5 \mathrm{~m}$, near Larissa $\left(39^{\circ} 40^{\prime} \mathrm{N}\right.$ Lat, $22^{\circ} 16^{\prime} \mathrm{E}$ Long), overlain by clay and sands. Coll. 1960 and subm. by Horst Schneider, Geol. Inst. der Univ., Saarbrücken, Germany. Comment: position of sample just underneath Würm gravels, as well as neighbouring finds of Elephas antiquus and Levallois-Mousterian tools, point to a Riss-Würm Interstadial age.

\section{Lipari series, Italy}

Charred wood from varying exposures in volcanic mud and ashes. Coll. 1965 and subm. by Hans Pichler, Mineral. Inst. der Univ., Tübingen, Germany. Samples date individual eruptions of younger volcanos.

Hv-1021. Lipari, $1.5 \mathrm{~m}$

$3270 \pm 100$

Sample from weathered layer imbedded in pumice $\left(38^{\circ} 30^{\prime} 25^{\prime \prime} \mathrm{N}\right.$ Lat, $14^{\circ} 56^{\prime} 22^{\prime \prime} \mathrm{E}$ Long); dated as Neolithic from the discovery of obsidian blades. 
Hv-564. Lipari, $2.0 \mathrm{~m}$

15,350 в.c.

Sample from weathered layer imbedded in pumice $\left(38^{\circ} 31^{\prime} 11^{\prime \prime} \mathrm{N}\right.$ Lat, $14^{\circ} 55^{\prime} 42^{\prime \prime}$ E Long); dated as Neolithic because of obsidian finds.

Hv-1020. Lipari, $2.5 \mathrm{~m}$

$1765 \pm 95$

Sample from weathered layer imbedded in pumice $\left(38^{\circ} 30^{\prime} 10^{\prime \prime} \mathrm{N}\right.$ Lat, $14^{\circ} 47^{\prime} 10^{\prime \prime} \mathrm{E}$ Long), from same stratigraphical layer as $\mathrm{Hv}-1021$.

\section{Hv-1019. Lipari, $4.0 \mathrm{~m}$}

$2875 \pm 110$

Sample from weathered horizon imbedded in pumice $\left(38^{\circ} 30^{\prime} 18^{\prime \prime}\right.$ $\mathrm{N}$ Lat, $14^{\circ} 57^{\prime} 38^{\prime \prime} \mathrm{E}$ Long), from same stratigraphical position as Hv-1021.

\section{Hv-1022. Lipari, $4.5 \mathrm{~m}$}

Sample from older pumice sequence (Cycle III) $\left(38^{\circ} 30^{\prime} 18^{\prime \prime} \mathrm{N}\right.$ Lat, $14^{\circ} 56^{\prime} 43^{\prime \prime}$ E Long); according to stratigraphical position, a Pleistocene age was assumed.

\section{Hv-1024. Roccamonfina, $5.0 \mathrm{~m}$} E Long).

Sample imbedded in volcanic ejecta $\left(41^{\circ} 20^{\prime} 40^{\prime \prime} \mathrm{N}\right.$ Lat, $14^{\circ} 00^{\prime} 58^{\prime \prime}$

General Comment: according to artifact finds in the weathered layer, a new classification places Hv-564 in the young Paleolithic. $\mathrm{Hv}-1019$, Hv-1020 and Hv-1021 were assigned to the Neolithic, and their $\mathrm{C}^{14}$ dates are not explained. Dates of $\mathrm{Hv}-1022$ and $\mathrm{Hv}-1024$ correspond to geological results.

\section{Hv-809. Penbé, France}

$$
660 \pm 75
$$

Oyster shells, depth 50 to $60 \mathrm{~m}$, from an exposure in Atlantic Ocean seacliff on Penbé Bay (47 $30^{\prime} \mathrm{N}$ Lat, $20^{\circ} 38^{\prime} \mathrm{W}$ Long), overlain by 10 $\mathrm{m}$ of humice sand and $50 \mathrm{~m}$ of periglacial debris. Sample lav within spray range of the surf. Coll. 1964 and subm. by Horst Schülke, Geol. Inst. der Univ., Saarlouis. Comment: stratigraphic situation indicated a Würm-Interstadial age. Anomalous $\mathrm{C}^{14}$ age may be caused by exchange with bicarbonate of modern seawater, age of which is approx. $450 \mathrm{yr}$ (Eriksen and Olsson, 1963).

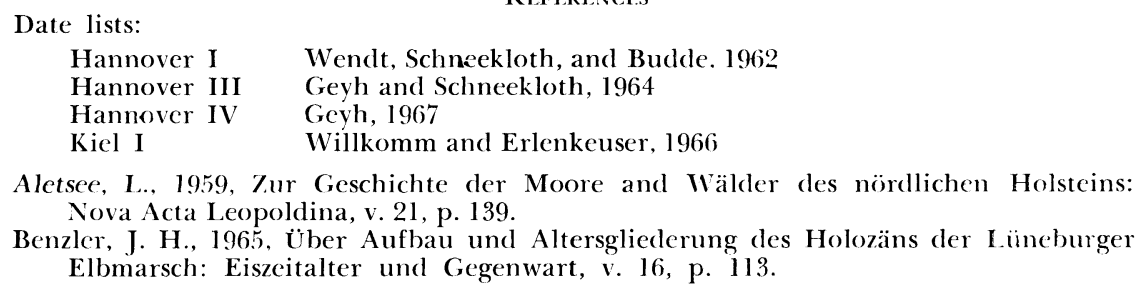


Brand, G., Hagemann, B. P., Jelgersma, S., and Sindowski, K. H., 1965, Die lithostratigraphische Unterteilung des marinen Holozäns an der Nordsecküste: Geol. Jahrb., v. 82 , p. 365 .

De Jong, J. D., 1960, The morphological evolution of the Dutch coast: Geologie en Mijnbouw, v. 39, p. 638.

Eriksson, K. G. and Olsson, I. U.: 1963, Some problems in connection with ${ }^{14} \mathrm{C}$-dating of tests of foraminifera: Bull. Geol. Inst. of Univ. Uppsala, v. 42, p. 1.

Firbas, F., 1949, Waldgeschichte Mitteleuropas: v. 1, Jena.

Canss, O., 1953, Ein fossilführendes Interglazial in den Berchtesgadener Alpen: Gcologica Bavarica, v. 19, p. 340.

Groschopf, P., 1961, Beiträge zur Holozänstratigraphie Südwestdeutschlands und "C. Bestimmungen: Geol. Landesamt. Baden-Württemberg, Jahreshefte, v. 4, p. 137.

Knörzer, K. H., 1949, Die Vegetation des Torfmoores im Solling und die nacheiszeitliche Waldgeschichte dieses Gebirges auf Grund der Pollenuntersuchungen: Staatsexamensarbeit an der Univ. Göttingen.

Kubitzki, K., 1961, Zur Synchronisierung der nordwesteuropäischen Pollendiagramme: Flora, v. 150, p. 43.

Lang, H. D., 1965, Ein geologisches Profil im Aller-Urstromtal in Celle: Ber. der Naturhist. Gesell., v. 109. p. 13.

I.ïclers, R.. 1964, Stark entwickclte Podsole unter Eichen-Birkenwald bei Voltlage im westlichen Niedersachsen und die Frage nach ihrem Alter: Zeitschr. für Pflanzenernährung, Düngung, Bodenkunde, v. 107 , p. 215.

I.̈̈ttig, G., 1965, Die lithostratigraphische Unterteilung des marinen Holozäns an der Nordseeküste: Vortrag anlässlich der 32. Tagung der NW-deutsch. Geol., Flensburg.

Macck, M. S., 1963, Die Entstehungsgeschichte der interglazialen Kalktuffe des Diessener Tals bei Aarb/Neckar: Dissert. an der Univ. Tübingen, Baden-Württemberg.

Müller, W', 1962, Ablauf der holozänen Meerestransgression an der südlichen Nordseekiuste und Folgerungen in Bezug auf eine geochronologische Holozängliederung: Eiszeitalter und Gegenwart, v. 13, p. 197.

Nietsch, H., 1958, Pollenanalytischer Beitrag zur Geschichte der Wesermarsch bei Bremen: Die Kunde, N.F., v. 7 , p. 72.

Schneekloth, H., 1965, Die Rekurrenzfläche im Grossen Moor bei Gifhorn-eine zcitgleiche Bildung?: Geol. Jahrb., v. 83, p. 477.

1967a, Altersunterschiede des Schwarz-Wieisstorfkontaktes in 8 Profilen aus dem Kehdinger Moor: Geol. Jahrb., v. 84, in press. _ 1967b, Vergleichende pollenanalytische und ${ }^{14} \mathrm{C}$-Datierungen an einigen Mooren im Solling: Geol. Jahrb., v. 84, in press.

Schüttrumpf, R., 1937, Das Interglazialprofil von Iauenburg/Elbe Kuhgrund II: Mitt. des Geol. Staatsinst. Hamburg, v. 16, p. 37.

Steckhan, H. K., 1961, Pollenanalytisch-vegetationsgeschichtliche Untersuchungen zur frühen Siedlungsgeschichte im Vogelsberg, Knüll und Solling: Flora, v. 150, p. 514 .

Steeger, A., 1952, 100 Jahre Eiszeitforschung im Niederrhein: Der Niederrhein, v. 19 , p. 57 .

Stoller, J., 1916, Ein Diluvialprofil am Steilufer der Werra bei Nienhagen: Jahrb. Preuss. Geol. L. A., v. 37, p. 225.

Straka, H., 1961, Relative und absolute Daticrungen quartärer Ablagerungen: Naturwissenschaften, v. 48 , p. 324 .

Wiermann, R., 1962, Botanisch-moorkundiiche Untersuchungen in Nordfriesland. Ein Beitrag zur Frage nach dem zeitlichen Ablauf der Meeresspiegelschwankungen: Meyniana, v. 12, p. 97.

_ $1966,{ }^{14} \mathrm{C}$-Daten zur Moor- und Marschengeschichte bei Bordelum (Nordfriesland) : Flora, v. 156, p. 237.

Willutzki, H., 1962, Zur Waldgeschichte und Vermoorung sowie über Rekurrenzflächen im Oberharz: Nova Acta Lcopoldina, N.F., v. 25, p. 52 , p. 160.

Woldstedt ,P., 1958, Das Eiszeitalter (Vol. II) ; Europa, Vorderasien und Nordafrika im Eiszeitalter: Stuttgart, Enke.

Zeuner, F. E., 1959, The Pleistocene period; its climate, chronology and faunal successions: London, Hutchinson, XVIII. 